\title{
Chapter 6 \\ Peru: A Wholesale Reform Fueled \\ by an Obsession with Learning and Equity
}

\author{
Jaime Saavedra and Marcela Gutierrez
}

\begin{abstract}
After decades of expansion, the Peruvian education system had relatively high levels of access, but low and heterogeneous quality. The depth of the learning crisis was seen in 2013, when Peru ranked last in PISA. The country responded by implementing an ambitious reform which built on previous efforts, which is described in detail in this chapter. The reform was composed of four pillars: (i) Revalorize teachers' career by making selection and promotion meritocratic, attracting the best into the profession, and supporting teacher professional development through school-based coaching; (ii) Improve the quality of learning for all by revising the curriculum, expanding early childhood education and full-day schooling, providing direct support to schools (through lesson plans and school grants) and carrying out several deep institutional reforms to the university system; (iii) Effective management of the school and the education system, including the use of learning assessment data for school planning. This entailed increasing school autonomy, introducing meritocracy in the selection of principals, and creating a culture of evidence-based decision making; and (iv) Close the infrastructure gap. The reform process required strong political and financial commitment and resulted in impressive improvements in student learning. Most importantly, it led to a change in mindsets towards a focus on learning.
\end{abstract}

\subsection{Introduction}

Peru has been growing steadily for the last 20 years, but economic growth has not been accompanied by a strong investment in human capital. During this time, there was a large expansion of the education system and enrollment rates steadily increased. However, financial investments were not accelerating at the same pace, and expenditures per pupil gradually fell. It was a clear case of a quantity and quality trade-off. Today, more children are in school, with net enrollment rates close to $100 \%$ at the primary level and $80 \%$ at the secondary level. Peru is a middle-income

J. Saavedra $(\triangle) \cdot$ M. Gutierrez

The World Bank, Washington, DC, USA

e-mail: jsaavedra@worldbank.org; mgutierrezb@worldbankgroup.org 
Fig. 6.1 Pillars of Peru's education reform
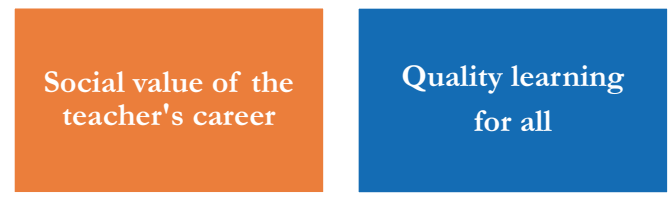

Effective

management of the education system
Closing the infrastructure gap

country which implemented first generation reforms that fostered economic growth since the nineties, but that did not include other structural reforms aimed at promoting equality of opportunities. Educational opportunities had expanded, but quality was low and heterogenous. There was more schooling, but not enough learning. There were more seats, but schools and teachers were not equipped to support children in developing the competencies, abilities and knowledge required to reach their fullest potential.

Since 2003, Peru has implemented a national system to measure learning rigorously using a national standardized exam for all 2 nd grade classrooms. Results consistently showed learning rates were low and relatively flat. But in November of 2013, Peru had its PISA shock when the 2012 PISA results were released after a ministerial change. Peru was in last place of all the 65 countries that had taken PISA - not the bottom $10 \%$ - but last. This was a shock for the country. The government could have decided to downplay the results, in saying 'but Peru has improved more than any other country since 2009' - which was true- or 'but we are better than many countries that didn't even take PISA' or 'it is an OECD examination that is alien to Peruvian culture and interests'. But that was not the chosen route. Instead, the government decided to own the problem and use these results to say "Look, we're not in trouble. We're in deep trouble." Education was on the front page of the main newspaper of the country. And education is never on the front page of the newspaper.

Peru subsequently went through an education reform process, which is still in the process of implementation, guided by an obsession with improving learning. The reform that was envisaged had four lines of action which needed to be pursued simultaneously and comprehensively: (i) revalorization of teachers' career; (ii) improvement of the quality of learning for all; (iii) effective management of the school system; and (iv) closing the infrastructure gap (Fig. 6.1).

The elements of the reform were consistent with a continuation of the National Plans that had been developed in previous years in consultation with many actors across the country (including the Plan Nacional de Educación para Todos 2005-2015). However, the reform still had to be well understood by the general public, teachers, businessmen, journalists, and the government itself. There was a perception that public education quality was low, that this was an inevitable fate, 
and that the sector was condemned to mediocrity. Actually, in the Annual Conference of Business Executives (CADE, for its acronym in Spanish) of 2012, one of the discussion topics was how the private sector could be used as a provider of education, given the understanding that the reforms needed in the public sector were short of impossible. So not only was a reform needed, but the reform had to be wellcommunicated and implementable, to clearly demonstrate to the public that change in the public sector- and improvement - was possible. There had to be a plan, but as important as that, there had to be a public perception that there was a clear and an implementable plan.

The low learning levels were accompanied by a very large heterogeneity in quality. Peru, as a highly unequal country, could trace a large portion of that inequality of outcomes to a profound inequality of opportunities. Parental socioeconomic background, location and ethnicity determined the quality of a child's education, as well as access to early childhood and tertiary education. For instance, differences in quality between public and private institutions were large, and even within those categories there was a lot of heterogeneity. Differences in quality between urban and rural schools were also immense. Given these inequities, the reform described here from 2013-2016 focused on improving the public system and provide more opportunities for the poor to access quality education.

There were many shortcomings of public education at the start of the reform. First, the school infrastructure was in a very poor condition; in part, because despite some investments over the years, current expenditures to maintain buildings were not included in the public budget. Textbooks were insufficient and would not arrive on time to all schools, and in many cases, there were school supplies' shortages. Almost all current expenditures were for teachers' salaries.

From the public's perspective, most of the problems of public education could be attributed to the lack of preparation and commitment of public teachers, who were seen as a group of unionized traditional public servants who only cared about their labor rights and job stability and not children's learning. In fact, there was a group of teachers that fit this perception, but many did not. There was a problem of motivation and low salaries, but there were also many teachers that were in the profession because of an intrinsic motivation. And the magic of learning comes from the interaction between teachers and students. Thus, reforming the teacher career path, attracting talented individuals to the profession, and getting the best possible performance out of the existing teachers were key elements of the reform.

\subsection{Increasing the Social Value of the Teaching Career}

A school is as good as its teachers. In the United States, students in a class with an effective teacher advance 1.5 grade levels or more over a single school year, compared with just 0.5 grade levels for those with an ineffective one (World Development Report 2018). Similar effects of the quality of teachers on learning are also found in Ecuador, Uganda, Pakistan and India (Bau and Das 2017). 


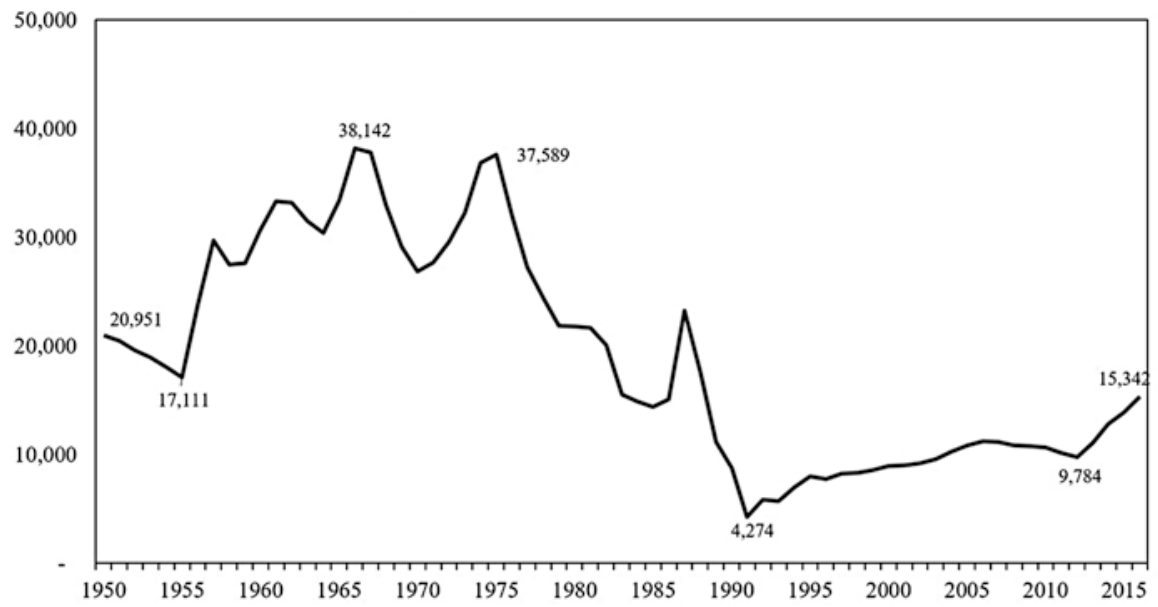

Fig. 6.2 Annual Peruvian teacher salary 1950-2016 (in constant prices of 2011, \$). (Reproduced from Nopo 2017, adapted and updated from GRADE (2004))

Beteille and Evans (2019) find that some of the most effective interventions to improve student learning rely on teachers. They compare the effect of three types of programs on student learning in low- and middle-income countries: teacherdriven interventions (e.g. structured pedagogy), community-based monitoring, and computer-assisted learning programs. They find that while teacher-driven interventions raised student's language scores by around 9 months, communitybased monitoring had half the effect and computer-assisted learning program less than one-twentieth. This is supported by other evidence, such as an analysis of the education systems with the best global performance, which concluded that country's learning levels depend on the quality of teachers and that the best interventions to improve learning involved teacher training (Barber and Mourshed 2007).

Despite this evidence, the teaching profession in Peru is not well paid. Professionals with similar characteristics to teachers in Peru received an average salary which was $42 \%$ higher than Peruvian teachers'. In fact, Peru is the second Latin American country with the greatest wage gap between teachers and other professionals (Mizala and Nopo 2016) (Fig. 6.2).

Until the 1970s, a teaching career was a typical profession in an emerging middle class. However, with the massification of education that started in that decade, teachers' salaries started falling slowly in real terms. By 2010, teachers' salaries were about one-third of what they were in the late 1960s (in real terms). The career lost social recognition slowly but steadily. Standards to hire teachers in the public system were lowered and the quality of pre-service institutions fell, while the number of institutions (including universities) increased. Teacher incentives were not related to performance or professionalism, and - most importantly - were not linked 
in any way to student learning. A survey applied by IPSOS, a polling firm, in $2015^{1}$ showed that most Peruvians did not have a positive perception of teaching: $30 \%$ believed teachers in public schools did low or very low-quality work, 55\% believed teaching was an easy job, and $64 \%$ would not want their children to pursue a teaching career, especially among those of higher socioeconomic status. Additionally, teachers themselves had a poor perception of their job: $63 \%$ thought that society minimizes the value of their profession and 53\% would not want their children to become teachers. ${ }^{2}$ Overall, Peruvian society looked upon teaching as a poor career choice.

Low wages and low social value, among others, decreased youth's interest in pursuing a teaching career. Between 1999 and 2012, the percentage of teachers under 35 years-old fell from $51 \%$ to $21 \%$. In the same period, the percentage of teachers over age 44 increased from $15 \%$ to $47 \%{ }^{3}$ Worryingly, the best graduates of secondary school did not describe teaching as their preferred professional path.

This situation is not unique to Peru. Elacqua et al. (2018) document this widespread phenomenon in Latin America. They observe that the rapid expansion of coverage between 1960 and 1980 required hiring a larger number of teachers. This could only be achieved by decreasing the standards to become a teacher and increasing the number of teacher training institutions- often without much regulation. As per pupil expenditures went down, the working conditions of teachers also decreased. Both factors contributed to the loss of prestige of the teaching career.

Elements of the reform to increase the social value of the teaching career:

- Ley de Reforma Magisterial

- Teacher Vocation Scholarship

- Evaluation for entering career

- Teacher promotion evaluations

- School Bonus

- Teacher Professional Development

The Teacher's Reform Law (the Ley de Reforma Magisterial) was passed in 2012. The Law aimed to attract and retain the best candidates into the teaching profession implementing a new teaching career pathway based on meritocracy. In this new pathway, entrance to the profession is based on teachers' effort and performance, and retention and promotion is related to performance, not only tenure and age. It also included a new scheme of professional development.

\footnotetext{
${ }^{1}$ IPSOS, 2015. This survey was requested by the Ministry of Education in 2015 and covered 16 cities.

${ }^{2}$ Encuesta Nacional a Docentes de Instituciones Educativas Públicas y Privadas (ENDO), 2014.

${ }^{3}$ Calculations from the Ministry of Education using the ENAHO 1997-1999 and 2010-2012.
} 


\subsubsection{Attracting and Selecting the Best Candidates into the Teaching Profession}

To incentivize secondary school graduates to become teachers, the Ministry launched the Teacher Vocation Scholarship (Beca Vocacion de Maestro) in 2014. This scholarship offered full merit-based funding for undergraduate studies in pedagogy in the best universities of the country. About 500 scholarships were awarded per year. Although it was a small number, it was a signal that the public sector was starting to attract good students into the career.

A huge challenge was the implementation of the mandates of the law, including executing a fair and transparent process of recruitment and retainment, intensifying in-service training, and improving the social value of the career (Vargas and Cuenca 2018). The first evaluations to enter the public teaching profession were implemented in 2015. There were 202,000 applicants for 19,632 government teaching jobs. Teachers were evaluated through a written test that measured their basic skills (reading comprehension and logic), curricular knowledge, pedagogy and specialty. Those with a minimum score went through a second phase of evaluation which required teaching a class and being directly assessed by peers. To ensure that the best performers joined the teaching career, the Ministry granted an economic incentive of USD 6000 to the top third of the teachers with the best scores in the examination process. ${ }^{4}$ This was consistent with a broader government strategy of giving more incentives to the best candidates to join the teaching career.

There were 20,000 job posts available but only 8137 teachers (out of the 202,000 applicants) were selected. This implied an entry rate of $4 \%$, which was more demanding than that of the most prestigious universities. Fifty-four percent went to work in rural schools. This process was complex from a pedagogical as well as a logistical perspective. It is not easy to correctly discern the best professionals with a written examination -which was used as a first stage, but it was too difficult to implement other methods given the numbers involved. Importantly, it was critical for the acceptance of the reform for the process to be perceived as fair, transparent and free of any hint of corruption or clientelism as had been common practice in the past. Part of the success of the process was that public opinion, and most importantly, teachers, saw this process as meritocratic and free of any political interference.

\subsubsection{Rewarding Teacher's Performance and Effort}

The first teacher promotion contests in more than 20 years were held in 2014. For the first time, promotions were not defined by years of service. More than 180,000 teachers participated, taking a written exam simultaneously in over 60 cities. Around

\footnotetext{
${ }^{4}$ This was done through the Bonus of Attraction to Public Teaching Post (Bono de Atracción a la Carrera Magisterial).
} 
one third received a promotion, moving forward in the teaching career scale and achieving an average salary increase of $32 \%$ (the actual raises ranged from $70 \%$ to $0 \%$ ). In the previous 5-year period, the salary increase had been only $8 \%$, and mostly flat. The exams were transparent, objective and fair, and there was no hint of corruption or clientelism. In the next 3 years, 11 evaluation processes were held with several opportunities for teachers to raise their salaries.

To incentivize teachers' effort and their focus on learning, a school bonus (Bono Escuela) was awarded to all teachers and principals who taught in schools that attained the largest student gains. ${ }^{5}$ The bonus was given to the top third of schools, which were ranked among schools of the same regions and according to changes in enrollment and retention rates, and well as school learning scores. A rigorous impact evaluation by León (2016) found that this incentive had a statistically significant positive impact on student learning, as well as on attendance of teachers and principals.

But incentives were not only monetary. The relationship with the union was complex but in general positive. To start, the union could have boycotted all examinations and evaluation processes, which didn't happen. Teachers, including union leaders, participated massively. The position of the Ministry was that teachers were part of the solution. Any improvement in quality of education depended necessarily on increased teacher participation and performance; all material inputs needed were important, but the human factor was the most critical. Teachers were partners in the reform. That was the constant message. Teachers were going to be better rewarded, but this would be based on performance and student learning. Some symbols were important. For example, there was a policy aimed at communicating directly with teachers. At the beginning of the school year, a text message to 180,000 teachers was sent across Peru saying "Maria, you are critical for education in Peru. We count on you to make sure that our students are the best. Signed, Jaime". Previously, teachers would have never received a personalized message from the minister. More opportunities were also established for teacher to show and share innovations, good practices and new ideas through national contests. Additionally, greater emphasis was placed on teacher health and welfare issues.

\subsubsection{Teacher's Professional Development}

The Ministry of Education approved new policy guidelines for in-service teacher training which present an articulated plan of systemic and diversified training which tackles the needs of new teachers and accompanies those that are already in classrooms by promoting a deepening of their knowledge and competencies.

\footnotetext{
${ }^{5}$ The School Bonus (Bono Escuela), implemented between 2014 and 2015, was received by 30,000 teachers and principals in more than 8000 primary schools. The bonus varies by type of educational institution and teacher (position and grade) oscillating between one and two monthly salaries.
} 
For the first time, in 2016 the Ministry implemented a Teacher Induction Program directed to those with less than 2 years of experience in public school teaching. This program aims to strengthen their professional and personal competencies, ease their labor insertion and promote their commitment and institutional responsibility. Experienced teachers act as mentors to new teachers for 6 months. In addition, new teachers can access online materials and remote guidance. In 2018, the program served 1694 newly hired teachers in 1559 schools and 26 regions. ${ }^{6}$

Further, in 2014 the Ministry also started implementing a continuous professional development program for teachers in community-based early childhood education centers and single-teacher/multi-grade primary schools. This is a school-centered permanent coaching program. It aims to provide planned, continuous, pertinent and contextualized guidance to teachers working in complex settings. The intervention includes school visits where immediate feedback is given to teachers after classroom observation, micro-workshops and courses, and refresher programs. Majerowicz and Montero (2018) evaluated this intervention and found it increased student learning outcomes between 0.25 and 0.38 standard deviations as measured by standardized tests. Importantly, the gains are not centered in highperforming students and benefit low-performing students equally. The author estimates that the impact persists for at least 1 year after the training ends. The program is relatively cost-effective with benefits that range from 0.72 to 1.12 standard deviations per 100-dollar investment, even taking into account teachers exiting the school system and the fact that training will wear off or become obsolete.

\subsection{Improving the Quality of Learning for all}

Peruvian schools aim to educate students who can innovate, be creative, ask questions and shape their own opinions. Students who have the tools to make the best use of their potential when becoming part of an increasingly challenging world. Students who later become engaged and caring citizens, committed to the development of the country. Achieving this requires a quality system which is guided by a modern curriculum. A system that gives every child the education that they requirewhich might not be the one required by others.

Elements of the reform to increase the social value of the teaching career:

- Curriculum update

- Pedagogical support to primary schools

- Full-day secondary schools

- Equality: bilingual intercultural education, special basic education, high performance schools, and alternative basic education

- Expansion of Early Childhood Education (ECE)

- Institutional arrangements for quality in higher education

- National Program of Scholarships and Educational Credit 


\subsubsection{Curriculum Update}

The process of reforming the National Curriculum (NC) starts in 2010, with the development of the learning standards (Tapia and Cueto 2017). Building on these advances to elaborate a new NC, the Ministry of Education carried out a nationwide consultation process between 2012 and 2016 with national and regional public sector institutions (including the National Council of Education), civil society, teachers, as well as national and international experts in curriculum structure and content (MINEDU 2017). In addition, the new NC took into account the results of reviews of curricula from a variety of countries and regions. The new NC was approved in June 2016. The NC establishes the learning outcomes that students are expected to reach by initial, primary, and secondary education. The NC is comprised of the "Exit Profile" of students of basic education, the cross-cutting approaches, and the curricular programs -per cycle of education- to develop the required competencies, among other components.

The "Exit Profiles" for students define 11 learning outcomes that students must reach by the end of basic education:

- The student recognizes herself as a valuable individual and identifies with her culture across different contexts.

- The student recognizes her rights and duties and understands the historical and social processes of Peru and the world.

- The student practices an active and healthy lifestyle, takes care of her physical health through day to day activities or sports.

- The student values artistic works and understands their contribution to culture and life in society. She is able to use art to communicate her ideas.

- The student communicates in her mother tongue, in Spanish as her second tongue (when her mother tongue is different), and in English as a foreign language.

- The student inquires and understands the natural and artificial world using scientific knowledge in dialogue with local knowledge to improve livelihoods and preserve nature.

- The student interprets reality and makes decisions based on mathematical knowledge adapted to her context.

- The student coordinates economic or social entrepreneurship projects in an ethical manner. These allow her to connect to the job market and the environmental, social, and economic development of her livelihood.

- The student responsibly uses communication and information technologies to learn and communicate.

- The student develops autonomous processes of learning to continuously improve her learning outcomes.

- The student understands and appreciates the spiritual and religious dimension of peoples' lives and society. 
The NC included seven cross-cutting approaches that should inform the pedagogical work of teachers in the classroom and relate to the competencies students should develop to achieve the exit profile (MINEDU 2016):

- Rights-based approach: Promotes the recognition of rights and duties of the student and promotes other democratic values such as liberty, responsibility, and collaboration.

- Inclusive and diversity aware approach: Teaches students to value all people equally and to avoid discrimination, exclusion, and inequality of opportunities.

- Intercultural approach: Promotes the interchange of ideas and experiences emerging from diverse cultural perspectives.

- Gender equality approach: Recognizes the need for equality of opportunity between males and females.

- Environmental approach: Seeks to educate students to take care of the environment.

- Common good approach: Promotes the development of socio-emotional skills such as empathy, solidarity, justice and equity.

- Pursuit of excellence approach: Incentivizes students to give their best effort to achieve their goals and contribute to their community.

There were several structural changes between the new NC and previous versions (Tapia and Cueto 2017). First, there was a stronger focus on learning, with a clear definition of learning process maps and standards that guided the expected levels of achievement per education cycle. The NC was competency oriented and practical. A competency is mastered through integrated learning resources and not through fragmented or disjointed teaching. There was a focus on progression and continuity in the student's learning process and a strong emphasis on in-class assessment as part of the overall planning and as a source of information to guide pedagogical practices on a day-to-day basis, and not only at the end of each cycle. Finally, gender equality was included as a cross-cutting approach. The objective was to emphasize the existence of similar rights, duties and opportunities for boys and girls, men and women. The Ministry of Education faced opposition by social conservative groups and was accused of promoting a "gender ideology" to destroy family principles (The Economist 2017), in part because of the inclusion in the curriculum of the teaching of tolerance and respect for sexual orientation and sexual education, which was a critical task in a country with very high levels of teenage pregnancy and gender-based violence. Political pressure led to some minor language modifications of the curriculum in March 2017 around concepts such as gender, sex, and sexuality.

The Ministry of Education planned for a progressive and gradual implementation of the NC, as it required a change in teaching practices. The NC was first implemented in 2017 in public and private primary schools in urban areas of the country, and after 2019 the Ministry expects to implement it in all modalities and school levels (RM 712-2018, MINEDU). 


\section{English and Physical Education}

In 2015 the National English Language Use and Teaching Policy was approved. Instead of teaching English for $2 \mathrm{~h}$ per week, high schools with full day schooling now include $5 \mathrm{~h}$ of English per week, using a blended learning system that combines self-learning software and face-to-face sessions. To provide this service, between 2015 and 2016 nearly 3000 face-to-face and virtual teachers were trained. 800 of these teachers participated in summer and winter school face-to-face trainings provided by the British Council and Pearson. Nearly 600 teachers were awarded scholarships to the United States and the United Kingdom, countries with which government-to-government agreements were signed.

The National Plan for Strengthening Physical Education and School Sports includes the extension of class time to $5 \mathrm{~h}$, as well as teacher training and the provision of sports equipment. As of 2016, 5076 physical education teacher slots had been created nationwide and 500,000 children and adolescents between 7 and 17 years of age performed physical training in adequate conditions. With this effort, which started in 2014, Physical Education returns to the regular curriculum, after being abandoned at the end of the 80 s.

\subsubsection{Pedagogical Support to Primary Schools}

To improve the quality of the learning process in primary schools, the Ministry implemented a Pedagogical Support (Soporte Pedagpogico) strategy with the following components: (i) support for teachers and principals through sample lesson plans to guide and facilitate teachers' work, training workshops for primary school teachers to foster creativity and innovation in pedagogical practices, mentors or coaches to guide teachers in their classrooms, peer-learning groups with teachers and principals, and virtual pedagogical counseling; (ii) personalized math and language tutoring for students in grades 1 through 3 with different learning styles; (iii) delivery and use of educational resources; and iv) community and parental involvement activities such as workshops with caregivers where they are taught how to support students' learning in everyday situations, or gatherings where parents and children can have fun and learn together. As of 2016, 1.1 million students (43\% of the total students in primary school) from 18 regions are in primary schools with Pedagogical Support.

It should be noted that the use of lesson plans was controversial. Some critics in the educational community argued that prescriptive lesson plans would reduce teacher's autonomy and creativity, and teachers should be free to prepare their classes independently following the guidance of the curriculum. The proposal however, was that the use of the lesson plans was not mandatory; teachers who wanted to prepare classes were welcomed to do so, but the lesson plans could serve as a base to those who could find it useful. The fact was that in most cases the teachers 
who complained were those in more advanced grades who did not receive lesson plans. These teachers demanded that lessons plans would be available for them as well.

\subsubsection{Full Day Secondary School (Jornada Escolar Completa, JEC)}

To cope with the rise in secondary school enrollment of the 1970s, the Peruvian secondary school day was divided into three shifts. The full-day secondary school model seeks to improve the quality of the educational service by extending the school schedule from 35 to 45 teaching hours per week which allows for more and better time teaching math, communication, English, sciences, physical education and job training. This model brought to public schools the same hours and school regime followed traditionally in all private schools. The new model includes revamped management with support from psychologists, social workers, tutors and pedagogical coordinators. It also includes better equipment and infrastructure. The model started in 2015 with 1000 schools (345,000 students), reached 1601 schools (more than half a million students) by 2016 and 2001 schools by 2017. The longterm objective is to reach all 8000 public secondary schools in Peru.

To ease the implementation of the curriculum, schools are receiving hardware, software, digital facilities and teacher training that links technology to the curriculum. For example, for the full-day secondary school model, laptops have been acquired and distributed, along with software licenses to integrate ICT in the English, communication, math and science courses. In addition, tablets are currently being distributed to primary schools in 15 regions of the country to be used as an educational resource.

Agüero (2016) evaluates the impact of this program and finds that it improved academic performance in math between 0.14 and 0.23 standard deviation in its first year. The program also had positive effects in communications in the first year, but these were less robust. These results are greater than the effects found in similar interventions in Latin America and are among the highest found worldwide. Importantly, the effects are higher in the poorest districts.

\subsubsection{Initiatives to Provide each Student with the Service That She or He Requires}

In the guiding thread of equality of opportunity, part of the narrative of the reform was that equality of opportunity implied very different services - and different expenditures per student- according to circumstances and needs. One critical dimension in Peru was the huge ethnolinguistic diversity. Peru has 55 native or indigenous 
communities which speak 47 different languages (Vílchez and Hurtado 2018). Thus, an important number of children in Peru speaks a language different from Spanish (e.g. quechua, aimara, awajún, shipibo-conibo, asháninka, etc.) at home. By law, all these children have the right to a bilingual intercultural education that teaches them to read and write in their home tongue and in Spanish (which is the national language together with quechua) so that they can fully participate socially and culturally. Peru is one of the countries that has made the most progress in the region in terms of bilingual intercultural education. The country has a strategy of cultural and linguistic strengthening which involves the production of materials, curriculum and teacher training. To date, more than 500 titles (workbooks, books for school libraries, curricular guides for teachers) have been produced in 19 native languages. Likewise, the competences of 9000 teachers have been strengthened through a coaching program. The latter has been rigorously evaluated; and it was found that receiving intercultural pedagogical support has an average impact on students learning of 28 percentage points in math and 21 in reading, which is equivalent to 0.28 and 0.29 standard deviations respectively (Majerowicz 2016a). Despite progress in terms of production of materials, Peru still lacks sufficient teachers that speak both Spanish and a native langue. By 2017, only about half of primary education students who required it had a trained teacher in their native tongue.

The Ministry also implemented a Special Basic Education strategy to serve children with any type of disability. It included, on one hand, strengthening the Special Basic Education Centers and, on the other, promoting the inclusion and increasingly better learning of students with mild or moderate disabilities in regular classrooms. As part of this strategy, 56 regular schools (1500 teachers) that already have expertise in the management of students with disabilities received training in inclusive education and specialized texts for various types of disabilities. In addition, and for the first time, regular schools received the necessary technological equipment to provide a quality service. Interpreters of Peruvian Sign Language have been hired in inclusive schools that serve students with hearing impairment in 7 regions of the country. Between 2015 and 2016, 26 Special Basic Education Resource Centers were created throughout the country to support the work of regular schools with students with disabilities. Between 2013 and 2016, the budget for Special Basic Education tripled, but despite that increase, still only about $25 \%$ of children with special needs had the required services.

Third, the Ministry created a network of High-Performance Schools (Colegios de Alto Rendimiento, COAR) to serve exceptionally talented youth, similar to magnet schools in the US. COARs were public boarding schools designed to give talented young people the possibility of developing their full potential using a more demanding curriculum. These schools were certified by the International Baccalaureate (IB) which provided an internationally recognized high standard. ${ }^{7}$ Each COAR serves 100 students per grade, selected meritocratically by demonstrating their academic, athletic or artistic excellence and covers the last three grades of

\footnotetext{
${ }^{7}$ https://www.ibo.org/programmes/diploma-programme/what-is-the-dp/
} 
secondary education. IB schools existed previously in Peru but only in a few private fee-based elite schools, so this network provided for the first-time meritocratic access to an IB education for free. Between 2014 and 2016 the system expanded such that there was one COAR per region, serving a total of 4350 students nationwide. After the expansion of the program, there are more students studying in an IB school in the public than in the private system Most teachers in those schools were public school teachers that received additional training but returned to their schools of origin after 2 years. An impact evaluation of this program, implemented by the CAF and the Ministry of Education, is currently underway.

\subsubsection{Expansion of Early Childhood Education Services}

Access to early childhood education for children aged 3-5 years in Peru was much lower among the poor, so it was a policy priority to expand coverage. From 2011 to 2016 , the net attendance rate increased from $73 \%$ to $86 \%$. In this period, more than 4150 villages in rural areas received early childhood services for the first time. This led to a complete elimination of the urban-rural access gap. Educational resources and materials were provided to existing and new early childhood centers and more than 3000 teachers were trained on initial education. Rigorous impact evaluations find that participating in public early childhood interventions had a positive effect of 8.7 points in reading comprehension and 2.5 points in math among second grade students (Majerowicz 2016b).

\subsubsection{Institutional Arrangements for Quality in Higher Education}

The tertiary education system in Peru had expanded during the last two decades. And as observed in many emerging economies, the expansion was fast and chaotic. The system was almost completely unregulated and about $90 \%$ of the growth in higher education enrollment was explained by an expansion of the private sector, and with an extreme heterogeneity in quality. After decades of chaos a new university law (Ley Universitaria) was promulgated in July 2014. The law defined the Peruvian university system as one of academically autonomous public and private institutions responsible for training professionals and citizens, that prioritized research, and is responsible for contributing to solving the country's development challenges.

The Quality Assurance Policy of Higher University Education was also approved, establishing four pillars for quality improvement: (i) Management and Information Systems, (ii) Quality improvement, (iii) Accreditation for continuous improvement and (iv) Licensing as a guarantee of basic quality conditions. 
For instance, as part of the first pillar, "Ponte en Carrera" (www.ponteencarrera. pe) was launched in July 2015. Ponte en Carrera is a virtual platform that offers detailed labor market outcomes information. The portal offers information on the income earned from different careers according to university or technical institute, as well as the characteristics of educational institutions. Yamada et al. (2016) analyze the social value of information using the data of this portal. They find that only $62 \%$ of the university-career combinations have a positive economic return. Thus, they estimate a high social value for the portal given that if only $1 \%$ of recent graduates that opted for a career in a university with a negative return had instead entered the labor market directly (given that the information of that negative return is now available), they would gain 4.5 million Peruvian soles (USD 1.3 million) additional earnings during their lifetime.

As mandated by the new Law, the National Superintendence of Higher University Education (SUNEDU) was created. This entity is in charge of licensing universities based on basic quality standards and overseeing the proper use of public resources. In the case of public institutions, this is because they are almost exclusively financed by public funds, and in the case of private institutions, because they were exempt of any sales tax and enjoyed an extremely generous income tax regime. In November 2015, the SUNEDU approved the Basic Quality Conditions. In December, it approved the Regulation of Infractions and Sanctions. The licensing process began in 2016. The vast majority of private universities have adapted their statutes to the new Law, while most public universities have renewed their authorities with the universal voting mechanisms established by the Law.

The approval of the Law and, in particular, the implementation of a new regulatory framework and the establishment of a new regulatory agency was politically very contentious. In a pattern that is observed throughout emerging economies, and in particular in South Asia and Africa, owners of low-quality private universities usually have political representation and were not in agreement with the establishment of basic standards or more stringent supervision of the use of tax exemptions. Despite the government having a relative majority in Congress at that time, the Law was passed by a slim margin, and in part by public opinion being very favorable to the establishment of more effective regulation of universities. The law was contested in court several times and a legal action was filed with the Constitutional Tribunal. In all instances, the University Law was cleared. Moreover, very strong political support was received from student organizations from both public and private universities, who on several occasions vocally expressed their support for the reforms via social media and public demonstrations. ${ }^{8}$

\footnotetext{
${ }^{8}$ Five years after the Law was approved, about 60 universities obtained a license to operate, several others were under supervision, and 4 universities were under closure process.
} 


\subsubsection{National Program of Scholarships and Educational Credit}

A government priority was to increase access of the poor to quality higher education. For the first time, a national policy of large-scale public scholarships was established in 2012. The National Program of Scholarships and Educational Credit (PRONABEC) delivered almost 100,000 scholarships between 2012 and 2016, reaching an annual budget of USD 280 million, making it one of the largest public fellowship programs in Latin America. PRONABEC has several scholarships including the following:

- Beca 18 offered full scholarships for undergraduate studies of Peruvian youth with high academic achievement from low socioeconomic backgrounds. From 2011 to 2016, it has financed undergraduate studies for almost 50,000 Peruvian youth with limited resources from $94 \%$ of the country's districts. Rigorous evaluations find that the program increases the probability of access to higher education (33 percentage points to universities and 40 percentage points to institutes) and student welfare. Further, those that receive the scholarship tend to access better universities and start studying earlier. However, fellows report higher levels of perceived discrimination and have a lower percentage of approved classes (which could be linked to them accessing higher quality institutions) (MEF 2019).

- Beca Presidente de la Republica, supports postgraduate studies (Masters and $\mathrm{PhDs}$ ) in prestigious universities that rank among the top 400 according to the main global rankings. The scholarships cover all expenses. Applicants must be among the top third of their undergraduate cohort, have an admission letter from a top university, and demonstrate that his/her monthly income is insufficient to pay for their postgraduate degrees. By 2016, it had been awarded to almost 1500 fellows.

- Beca Docente Universitario finances Masters and specialization studies for public university teachers in recognized universities in Peru and abroad. By 2016, 11,742 teachers had benefitted.

- In 2015, the Beca Doble Oportunidad was launched for young people who did not complete high school. Through it, beneficiaries can finish studying the 5th grade of secondary school and obtain a technical certification.

The Peruvian government also launched an educational loan called Credito 18 in 2015. It allows young people to access the best universities and institutes in Peru' using their own future incomes as a loan guarantee. The program only involves institutions whose graduates have high employability and are willing to guarantee $50 / 50$ of the loan with the state. The credit is only accessed by young people that attain high grades in high school and throughout their university career.

\footnotetext{
${ }^{9}$ Universidad Católica, Universidad del Pacífico, Universidad Cayetano Heredia, Universidad de Piura, UTEC y TECSUP.
} 


\subsection{Effective Management of the School System}

The Peruvian education system needs to provide a daily quality service to almost seven million students and their families in 52,000 public schools. In the case of Peru, the public sector provides the service and also regulates private sector provision. Thus, it also needs to regulate the activities of thousands of private providers. Additionally, the system administers 800 technological and pedagogical institutes and regulates almost 150 universities. The system is managed by 3500 staff who work in the Ministry of Education; close to 4000 government officials who work in the 25 Regional Directorates of Education (Direcciones Regionales de Educacion, DRE) and 220 Local Education Management Units (Unidades de Gestion Local, UGEL); around 380,000 teachers and school principals who work in public schools; and 100,000 teachers and principals in the private sector.

The educational service is a very complex service to provide and regulate. The education system shapes people's lives. It must equip students with knowledge, values and life-skills that enable them to become citizens that define their own destiny and attain a productive and fulfilled life. One thing that is not always emphasized in education reforms is that such a complex service requires a highly qualified multidisciplinary bureaucracy, even in systems where schools enjoy autonomy. The quality of the service, and the implementation of all reforms mentioned in this chapter depends on management. Designing, implementing, evaluating and constantly adapting the provision of services requires a management that allocates tasks and monitors their completion, sets the pace of work and administers human and physical resources effectively.

At the establishment level, the quality of school management has a very high impact on the effectiveness of teachers, on the quality of the service provided, and on the operation of the institution as a whole. Evidence supports this claim: "Correlational evidence from within and across countries..., coupled with a growing number of impact evaluations, show that higher-skilled managers and the use of effective management practices improve teaching and learning. Evidence from across countries participating in PISA supports this idea: moving from the bottom to the top quartile of school management quality is associated with approximately an additional 3 months of schooling for one year alone" (pg. 2, Adelman and Lemos, forthcoming). Barber and Mourshed (2007) reference The National College for School Leadership (2006) regarding their findings of diverse studies which show that schools that achieve good performance in student learning might differ in their management practices, but all share the characteristic of having good school leadership from their director.

Despite the importance of management in the education system, management of public schools in Peru was characterized by a rigid organizational structure in which principals devoted an extremely large amount of time to administrative tasks, which were not centered on learning or flexible to fit the different contexts of the country 
(MINEDU 2005). Principals also lacked administrative support staff. ${ }^{10}$ The principal was supposed to perform many administrative activities in schools where there were no other personnel aside from principals and teachers. In Peru, there were 32,000 administrative staff to support 50,000 schools which means there was less than one administrative staff person per school. ${ }^{11}$ This resulted in most principals focusing on routine and administrative work and having little time for pedagogical leadership and human resource management. Regional units faced similar challenges. In fact, in 2013, only $30 \%$ of the local education management units personnel provided pedagogical support to schools (the remaining $70 \%$ performed administrative tasks).

Elements of the reform to foster effective management of the education system:

- Strengthening school management: boosting the role of principals and hiring administrative staff

- Improving management in the middle and central level: modernizing processes, creating commitments of performance

- Improving data collection and use

The modernization of educational management was focused primarily on strengthening the management of individual schools, recognizing them as complex institutions to administer that required strong and independent leadership and adequate staff. Progress was made in redefining the role of the school principal and improving their selection. For the first time in 2015, 15,000 -in about a third of existing schools- school principal positions were assigned based on a meritocratic process. Further, training processes for principals were improved and school principals started receiving specialized training in school management. Finally, principals received greater autonomy and are now responsible for the use and allocation of minor maintenance and purchase resources, and for the first time they are part of the process of appointing teachers.

To support the role of principals, the reform also included recruitment of administrative workers. In 2015, about 8000 administrative positions (psychologists or social workers, administrators, secretaries, caretakers, cleaning and maintenance staff) were hired for the 1000 secondary schools that benefitted from full-day schooling. This policy continued in the 600 additional JEC schools that started operating in 2016 aiming to gradually close the gap in administrative personnel in schools.

\footnotetext{
${ }^{10}$ While most private schools have administrative and finance staff, psychologists, security personnel, and coordinators of different tasks, public schools are usually only composed of the principal and its teachers.

${ }^{11}$ Información del personal no docente en primaria y secundaria obtenida del Escale en base al Censo Escolar 2013.
} 
The reform also included improvements to middle management in the education system (the Regional Directorates of Education (DRE) and Local Educational Management Units (UGEL)) and in the Ministry or central level. For example, Performance Commitments (Compromisos de Desempeño) were designed as a tool to allow the transfer of additional resources to DREs based on their performance on sector's priority goals. These goals were linked to improving the planning processes, having the conditions for an adequate start of the school year and improving management throughout the year. Further, the Ministry of Education underwent a substantial modernization process which included execution control mechanisms, dashboards and control panels, and a simplification of purchasing processes.

Finally, information systems were strengthened to counter the lack of information about what was effectively happening at the school level, UGEL and DRE levels, and aggregate level. One such initiatives was the School Traffic Light (Semaforo Escuela) tool. This management tool collects critical information about school functioning: attendance of students, teachers, principals; availability of educational materials; and access to basic services. During 2015, 32,000 educational institutions were visited and more than 250,000 teachers were interviewed. In 2016, data of more than 10,000 additional schools was added. Currently, the tool covers the entirety of the system. The School Traffic Light generates representative information of the 220 UGELs on a monthly basis and serves as a means of accountability for school principals and the UGEL. The data generated allowed to public data at the UGEL (roughly similar to provincial) and regional level. As expected, initially the publication of data in, say, teacher absenteeism was not well received by some regional governors, but those reactions, were in the long run, a good symptom that the availability of public information creates incentives for governments to increase the quality of its services.

\subsection{Closing the Education Infrastructure Gap}

Having minimum infrastructure is critical to achieve student learning. Murillo and Román (2011) find that although there are differences between countries, the availability of basic infrastructure and services (electricity, water, sewage) and didactic resources (libraries, labs, sport facilities, books, computers) has an effect on student achievement levels in primary education in Latin America. Leon and Valdivia (2015) use Peruvian data and find a significant effect of school resources on academic achievement. They state that previous estimates of the school effects underestimate the relevance of school resources, particularly on the poorest areas. 
Elements of the reform to close the infrastructure gap:

- Census of Educational Infrastructure

- Increased investment

- Program of Maintenance of Educational Infrastructure

- Creation of PRONIED

- Innovative initiatives for specific regions

- Public Private Partnerships and Public Works Tax Deduction Programs

In 2014 the National Institute of Statistics and Informatics (INEI) collaborated with the Ministry of Education to assess the status of the infrastructure of the public education sector for the first time in the history of Peru. The Education Infrastructure Census showed a dire scenario: 7 of every 10 schools needed to be strengthened or reconstructed, $60 \%$ of schools had high seismic risk, one third of the plots lacked physical or legal resolution, and more than $80 \%$ of rural schools lacked access to water and sewage. After decades of insufficient investment and lack of maintenance, the Peruvian education system accumulated a deficit of basic educational infrastructure of more than US\$20 billion approximately $10 \%$ of GDP. The number reached USD 23 million when taking on account investments required for the conversion of the whole secondary school system to a single shift, the universalization of early childhood education and the improvements of multi-grade schools - including necessary furniture and equipment (MINEDU 2016).

The government also accelerated its investment in education. From 2011 and 2015 , public investment in infrastructure for education - including all levels of government - exceeded the equivalent of USD 5 billion (15,000 million Peruvian soles); $150 \%$ higher than in the previous 5 years. These investments financed the rehabilitation or construction of about 4000 schools nationwide. Most of the investments took place in the rural areas: in 2016 the per student investment in infrastructure in rural areas was 6.5 times that of urban areas.

To ensure the sustainability of school infrastructure, the Program of Maintenance of Educational Infrastructure was created in 2012. This program increased the resources received by principals and schools to maintain the school infrastructure. Until 2016, it had financed more than 1800 million Peruvian soles (USD 530 million) in repairs for more than 50,000 schools.

To increase the efficiency of the management of infrastructure investments made by the central government (Ministry of Education) and accelerate the process of closing the educational infrastructure gap, the National Educational Infrastructure Program (PRONIED, for its acronym in Spanish) was created in 2014 with administrative and financial autonomy. The institution created standard construction models that increased the speed with which technical construction files were generated and established monitoring systems that tracked every project.

The education reform included innovative infrastructure investments tailored to the needs of particular regions or students. For instance, PRONIED started implementing the Plan Selva in 2014. This plan targeted jungle communities which had 
amongst the highest infrastructure needs countrywide. Before Plan Selva, schools in the jungle were built in the same ways as in cities: with concrete. These structures were not well suited for the jungle as they were not resistant to the heavy rains and reached high temperatures in the summer. The Plan Selva designed and built schools that suited the area: made out of wood, with solar panels and special roofs that could withhold the rain and help manage the heavy temperatures; built high above the ground to avoid flooding when the river grew. The first set of ten schools earned second place in the recognized architectural prize of the Venice Biennale (MINEDU 2016).

To increase the speed in closing the infrastructure gap, the Ministry of Education increased cooperation with the private sector through Public Private Partnerships (PPPs) and Public Works Tax Deduction (Obras por Impuestos, OxI). PPPs started being designed in 2014. By 2016, education PPPs were formulated to address the infrastructure challenge for 66 schools, 7 COAR and 3 higher education technological institutes (with a potential investment of 2200 million Peruvian Soles-USD 648 million).

\subsection{Financing}

In 2003, a National Agreement signed by all political parties, business councils, and civil society organizations agreed to an annual increase in educational expenditures of $0.25 \%$ of GDP, starting from a base of about $3 \%$ of GDP until reaching $6 \%$ of GDP. Ten years later, expenditures were still around 3\% of GDP. To implement the educational reform, between 2011 and 2016, the education budget grew from $2.8 \%$ to $3.9 \%$ as a percentage of GDP, and $88 \%$ in nominal terms. This is reflected in the educational budget as a percentage of the total state budget increasing from $15 \%$ to $18 \%$. This has been a significant and unprecedented increase.

The increase in resources came accompanied by a higher pressure to spend faster and better. Traditionally, a significant portion of the budget assigned was not effectively spent. To accelerate spending, several measures were taken: there was a mechanism of "single balance window" which allowed ministry units which were underspending to release fund to other units; closer supervision of procurement processes to shorten timelines, and dashboards to identify administrative bottlenecks, among others. This allowed for a dramatic increase in spending of all units under direct control of the ministry (which did not include, for example, public universities which were autonomous in their processes) (Figs. 6.3, 6.4, and 6.5).

The higher spending is reflected in a significant increase in per student spending in the three educational levels (early childhood education, primary and secondary). However, expenditures are still far from other Latin American countries or OECD countries. Despite the significant increase observed between 2011 and 2016, Peru was spending only about USD 1200 per student in primary education - less than Colombia, about half of what was spent in Chile and a fifth of the OECD average. The main route to continue to increase per pupil expenditures is not an increase in 


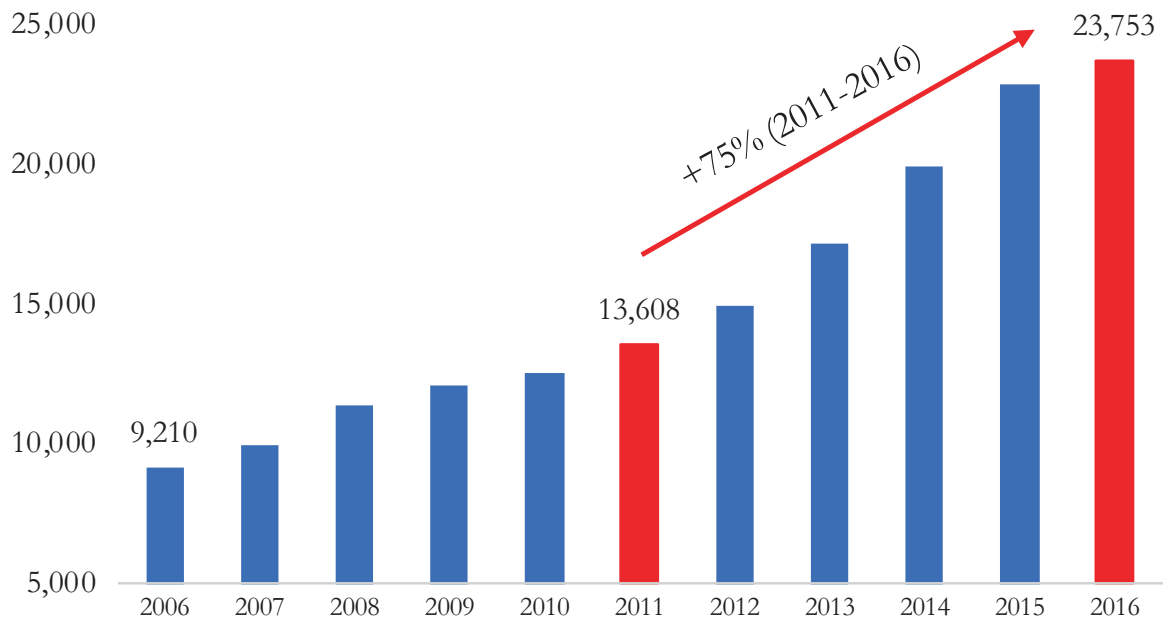

Fig. 6.3 Budget allocated to Education in millions of Soles. (Source: Ministry of Economy and Finance)

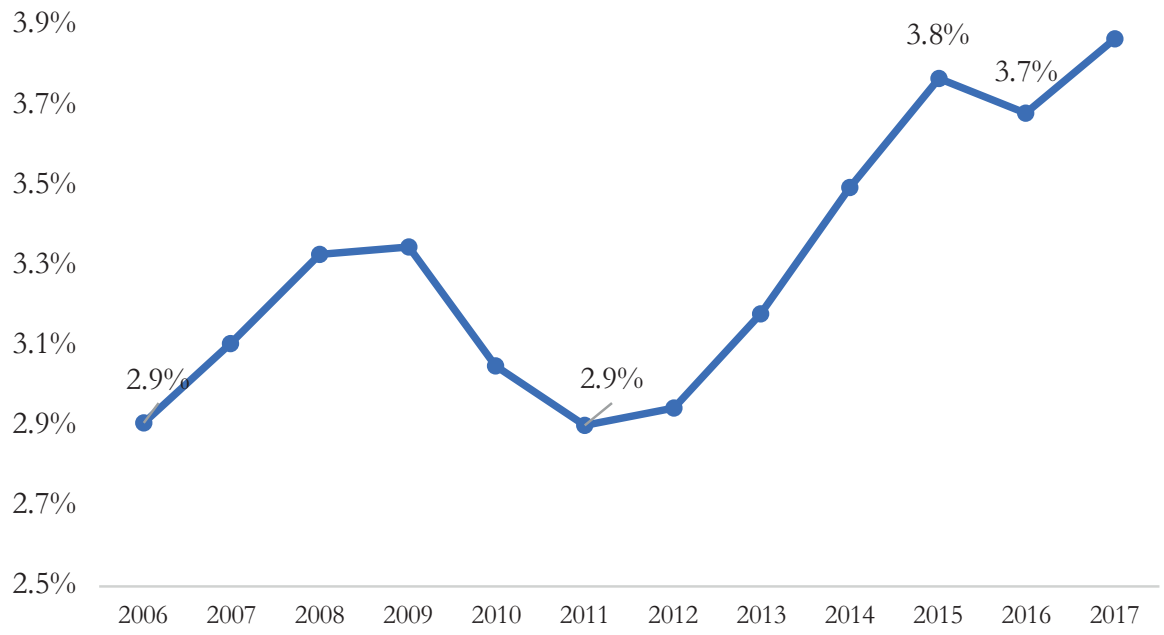

Fig. 6.4 Budget allocated to Education as a percentage of GDP. (Source: Ministry of Economy and Finance)

the share of education in the public budget; there is a small margin as it is already at almost $20 \%$ of the public budget. The main routes are to increase the size of the state, which in Peru is relatively small at about $16 \%$ of GDP because of low tax collection, and to continue a strong economic growth process. 


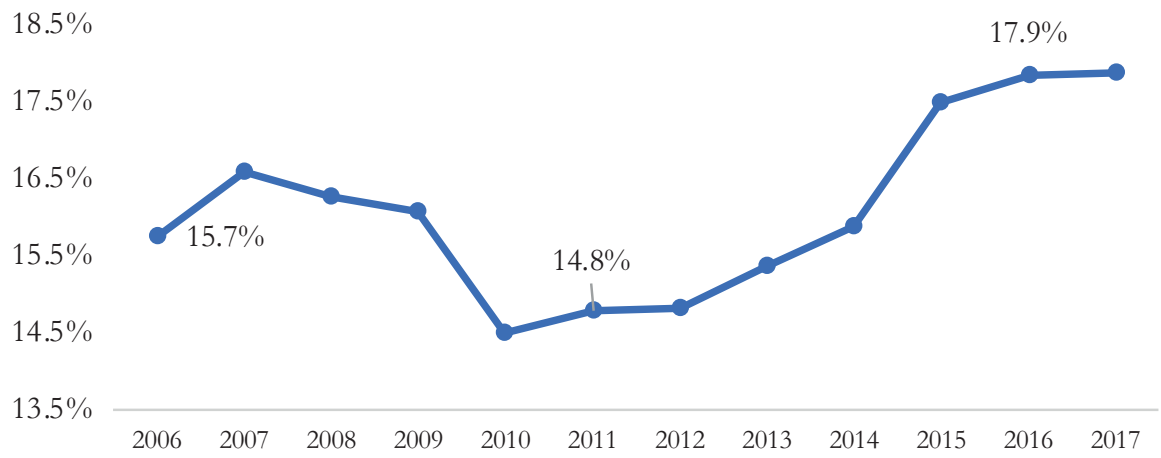

Fig. 6.5 Budget allocated to Education as a percentage of the total public budget. (Source: Ministry of Economy and Finance)

\subsection{Results in Student Learning}

Peru is the Latin American country with the largest progress in student test scores in PISA (Programme for International Student Assessment) for the period 2009 to 2015. ${ }^{12}$ Student outcomes have improved constantly, increasing $8 \%$ in reading and science and 6\% in math during the period 2009-2015. This growth is reflected in a lower number of students scoring below the minimum competences required to participate in society. This number decreased 10 percentage points in science, 7 percentage points in math, and 11 percentage points in reading. Importantly, Peru's improvement has been particularly stark among public institutions (Moreano et al. 2017). The biggest improvements in PISA scores took place from 2012 to 2015 , which coincides with the period in which the reform was implemented (2013-2016). The PISA results are consistent with other assessments. For instance, between 1997 and 2013, Peru participated in three LLECE (Latin American Laboratory for Assessment of the Quality of Education $)^{13}$ evaluations. These evaluations measure English, math and science competencies of students in third and sixth grade. When comparing 2013 with 2006, Peru presented substantial improvements in the three areas. A similar trend is seen in the National School Census data which, since 2007 evaluates all children in second grade in the subjects of math and reading comprehension. Between 2007 and 2013, the proportion of students with a satisfactory learning level in reading doubled, and the equivalent proportion in math tripled. In 2014, the largest growth in educational outcomes in the past 7 years was

\footnotetext{
${ }^{12}$ Peru's average score in Reading increased from 327 to 384 points. Although PISA evaluates math, science and reading competencies, only the latter is comparable across countries.

${ }^{13}$ The First Comparative and Exploratory Regional Study (Primer Estudio Regional Comparativo $y$ Explicativo, PERCE) in 1997, the Second Comparative and Exploratory Regional Study (Segundo Estudio Regional Comparativo y Explicativo, SERCE) in 2006, and the Third Comparative and Exploratory Regional Study (Tercer Estudio Regional Comparativo y Explicativo, TERCE) in 2013.
} 
Fig. 6.6 Evolution of Average Scores in PISA, Peruvian Students. (Source: OECD 2017)
Fig. 6.7 Evolution of Average Scores in LLECE, 6th grade Peruvian Students. (Source: Bilagher 2014)
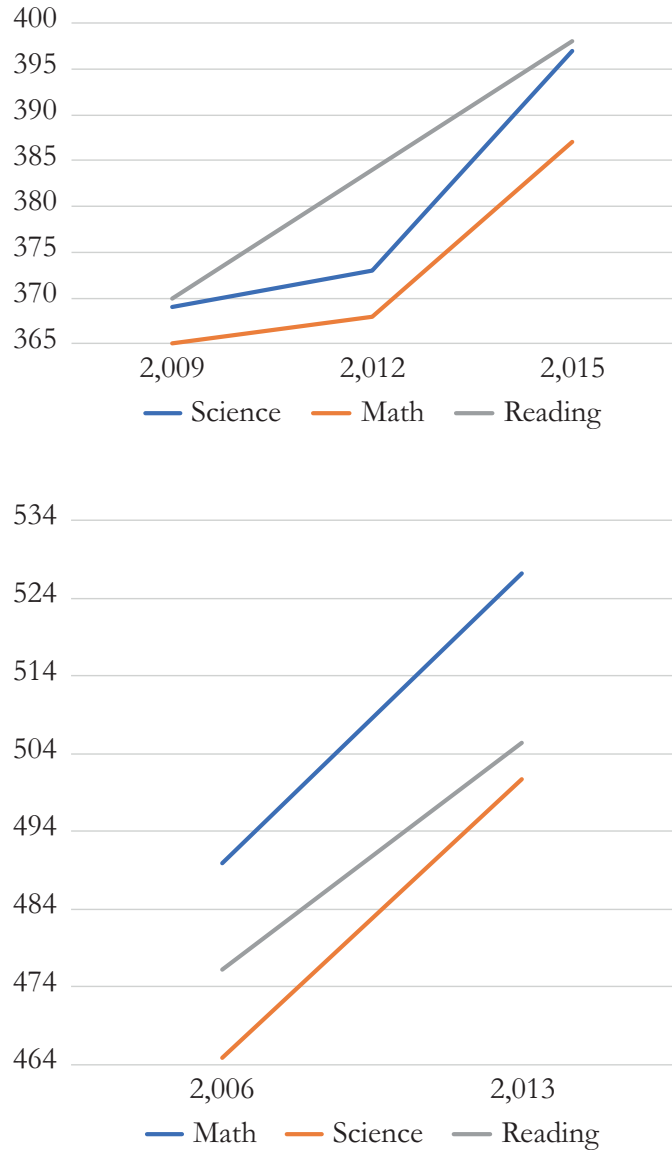

observed. From 2011 to 2015 , the percentage of students who reach the satisfactory level increased from $30 \%$ to $50 \%$ in Reading Comprehension and from $13 \%$ to $27 \%$ in Mathematics (Figs. 6.6, 6.7, 6.8, and 6.9).

\subsection{Pending Challenges}

Despite important recent advances, the challenges ahead are immense. The quality and equity of the Peruvian education system is still far from where it should be. For instance, most students still scored below the minimum proficiency threshold in PISA in 2015. The percentage of students that did not reach basic competencies was $58 \%$ in science, $66 \%$ in math, and $54 \%$ in reading. A similar picture is seen with the National School Census, where the percentage of second-grade children who scored below satisfactory level was $50 \%$ in reading comprehension and $73 \%$ in math. It 
Fig. 6.8 Evolution of Average Scores in LLECE, 3rd grade Peruvian Students. (Source: Bilagher 2014)

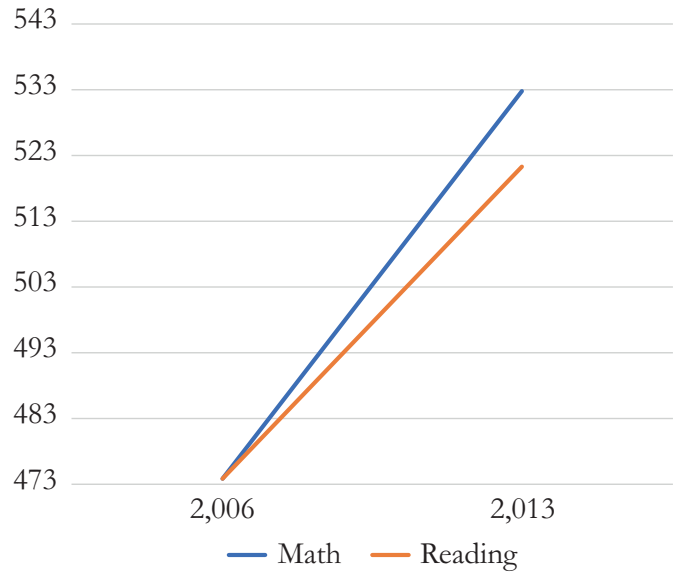

$60 \%$

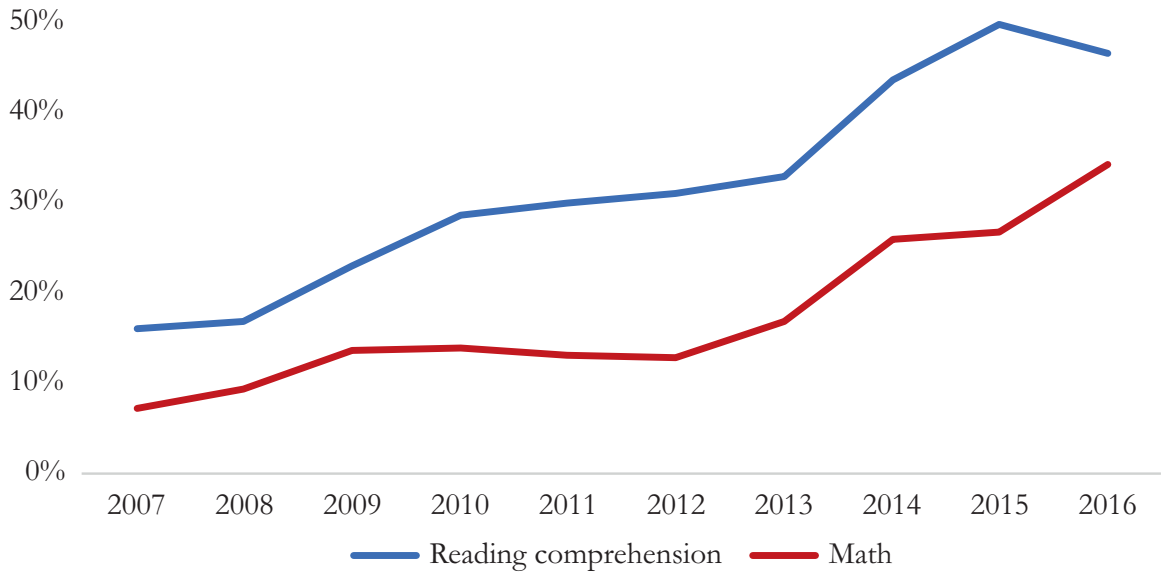

Fig. 6.9 Percentage of students with a satisfactory level in 2nd grade according to the National School Census. (Source: National School Census MINEDU)

was a dramatic improvement compared to previous years but is still an underperforming system.

Moreover, test scores reflect the inequality of the system. In PISA, those of lower socioeconomic background, from rural areas, and who attend public schools score lower than the rest (Moreano et al. 2017). Further, despite improvements, the differences between learning outcomes in rural and urban settings are still very big. Between 2007 and 2014, the percentage of students with a satisfactory level in reading went from $21 \%$ to $50 \%$ in urban areas, and from $6 \%$ to $17 \%$ in rural settings. The percentage of students with a satisfactory performance in math went from $9 \%$ to $30 \%$ in urban areas and $5 \%$ to $13 \%$ in rural ones (Fig. 6.10). 


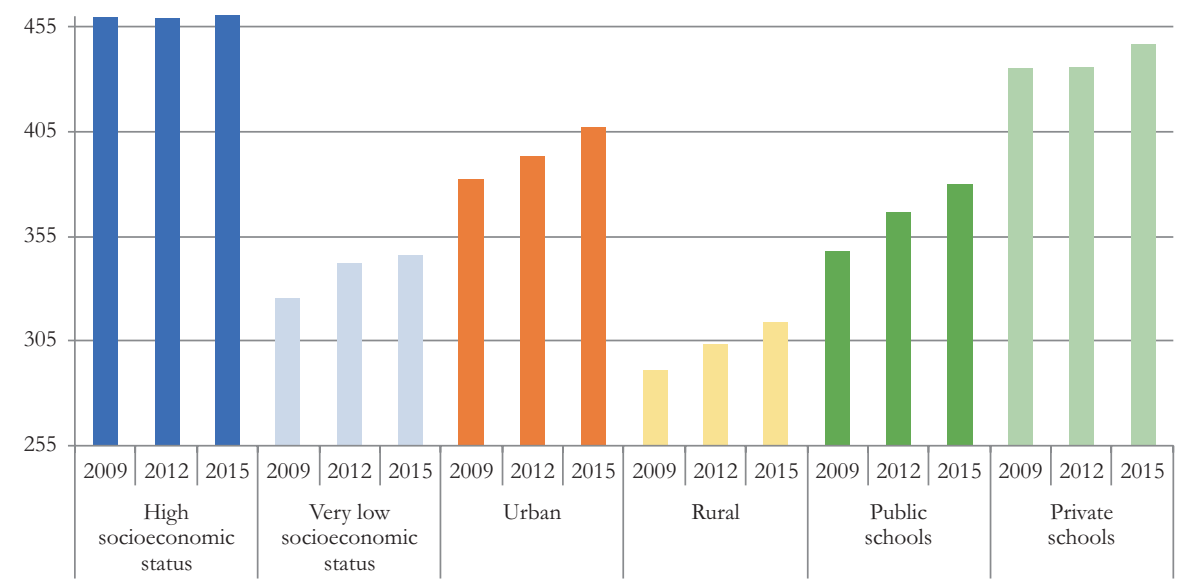

Fig. 6.10 Evolution of average scores in PISA by student and school's characteristics. (Source: Moreano et al. 2017)

Most of the policies described above will take years to be solidified and universalized. Early childhood education coverage is still not universal, especially if one limits the analysis to quality provision. As seen above, basic schooling does not provide each student with basic skills, let alone the opportunities that each student needs to develop to their fullest potential. Bilingualism has started but is still not complete and full-day secondary schooling is still not widespread. Higher education also has limitations both in access and quality. In 2013, only $39 \%$ of graduates from secondary school accessed higher education. ${ }^{14}$ Those that accessed did not enter a system that guarantees quality: out of the 140 universities in Peru, none is among the 500 best in the world ${ }^{15}$ and only 3 are among the 100 best universities of Latin America. ${ }^{16}$

Equity gaps have moved in the right direction. Gaps in access to early child education have closed, more students in secondary public schools have access to a full day school, as in any private school. Poor, talented children have access to a Higher Performance School (COAR) and to public fellowship for university studies. But urban-rural quality gaps in basic education are still large and access to good universities or technical institutions is easier for the rich.

Improving and expanding educational services will require an unprecedented financial effort and political commitment. By 2021, the bicentennial year of Peru, there is a commitment to double teachers' salaries (as compared to 2015). This will require continuing the process of increasing spending efficiency as well as a substantial increase in the budget. But what is most critical is to continue with an obsessive focus on learning and improving the quality of children's experiences in school. Continued investment in teachers requires a deepening of the meritocratic process

\footnotetext{
${ }^{14}$ Escale- Ministerio de Educación.

${ }^{15}$ QS Ranking 2013.

${ }^{16}$ QS Ranking 2013.
} 
in the selection and promotion of teachers and principals, and a deepening of a culture of continued professional development, if it is expected to have an impact on learning. The institutional changes required have been implemented and there is clear political and public support for maintaining a meritocratic career, free of any political interference or clientelism.

At the tertiary education level, the institutional changes that support the reforms that aim at increasing quality of the system have been advanced, and the political support of young people and the public opinion is clear. However, as in other countries, university reforms with dispersed winners (the current and future students) and concentrated, politically powerful losers (low quality institutions), the threat of change in the political balance is always present.

\section{References}

Agüero, J (2016). Evaluación de impacto de la Jornada Escolar Completa. Repositorio institucional - GRADE. http://repositorio.grade.org.pe/handle/GRADE/378. Accessed 22 Nov 2019.

Barber, M. \& Mourshed, M. (2007). How the world's best-performing schools systems come out on top. McKinsey \& Company. https://www.mckinsey.com/industries/social-sector/our-insights/ how-the-worlds-best-performing-school-systems-come-out-on-top. Accessed 22 Nov 2019.

Bau, N., \& Das, J. (2017). The misallocation of pay and productivity in the public sector: Evidence from the labor market for teachers. Washington, DC: The World Bank.

Beteille, T, \& Evans, D., (2019). Successful teachers, successful students: Recruiting and supporting society's most crucial professions. The World Bank's policy approach to teachers. http:// documents.worldbank.org/curated/en/235831548858735497/Successful-Teachers-SuccessfulStudents-Recruiting-and-Supporting-Society-s-Most-Crucial-Profession.pdf. Accessed 22 Nov 2019.

Bilagher, M. (2014). Resultados comparados SERCE-TERCE. UNESCO Regional Bureau for Education in Latin America and the Caribbean, Santiago de Chile. https://drive.google.com/ file/d/0BwzG1KOQMVTIVG5nOUV1LVIzM28/view. Accessed 22 Nov 2019.

Elacqua, G., Hincapie, D., Vegas, E., Alfonso, M., Montalva, V., \& Paredes, D. (2018). Profesión: Profesor en América Latina:¿ Por qué se perdió el prestigio docente y cómo recuperarlo?. InterAmerican Development Bank.

León Jara-Almonte, J., (2016). Evaluación de Impacto del Bono de Incentivo al Desempeño Escolar o "Bono Escuela". GRADE - Proyecto FORGE http://www.grade.org.pe/forge/descargas/Evaluaci\%C3\%B3n\%20Bono\%20Escuela\%20Juan\%20Le\%C3\%B3n.pdf. Accessed 22 Nov 2019.

Leon, G., \& Valdivia, M. (2015). Inequality in school resources and academic achievement: Evidence from Peru. International Journal of Educational Development, 40, 71-84. https:// doi.org/10.1016/j.ijedudev.2014.11.015.

Majerowicz, S. (2016a). Evaluaciones Rápidas de Impacto: Acompañamiento Pedagógico, Soporte Pedagógico Intercultural (ASPI) y Soporte Pedagógico. GRADE - Proyecto FORGE http://www.grade.org.pe/forge/descargas/evaluaciones\%20rapidas\%20de\%20impacto\%20 Majerowicz.pdf. Accessed 22 Nov 2019.

Majerowicz, S. (2016b). Impacto de educación inicial sobre desempeño académico. GRADE - Proyecto FORGE. http://www.grade.org.pe/forge/descargas/Impacto\%20de\%20 educaci\%C3\%B3n\%20inicial\%20Majerowicz.pdf. Accessed 22 Nov 2019.

Majerowicz, S. \& Montero, R., (2018). Working Paper. "Can Teaching be Taught? Experimental Evidence from a Teacher Coaching Program in Peru (Job Market Paper). https://scholar.harvard.edu/smajerowicz/publications/job-market-paper-can-teaching-be-taught-experimentalevidence-teacher. Accessed 22 Nov 2019. 
MEF. (2019). Evaluación de impacto del Programa Beca 18(Cohorte 2015-Modalidad Ordinaria). https://www.mef.gob.pe/contenidos/archivos-descarga/Informe_FINAL_Beca_2015_publicar. pdf. Accessed 26 Aug 2019.

MINEDU. (2005). Plan Nacional de Educación para Todos, Perú. Hacia una educación de calidad con equidad. Repositorio MINEDU. http://repositorio.minedu.gob.pe/handle/123456789/323. Accessed 22 Nov 2019.

MINEDU. (2016). Por una Educación con Dignidad. http://www.minedu.gob.pe/p/pdf/inversionen-infraestructura-educativa-2011\%E2\%80\%932016.pdf. Accessed 26 Aug 2019.

MINEDU. (2017). National curriculum of basic education. Lima: Ministry of Education.

Mizala, A., \& Nopo, H. (2016). Measuring the relative pay of school teachers in Latin America 1997-2007. International Journal of Educational Development, 47, 20-32. https://doi. org/10.1016/j.ijedudev.2015.11.014.

Moreano, G., Christiansen, A., Ramos, S., Saravia, J.C., Terrones, M., (2017). El Perú en PISA 2015: informe nacional de resultados. http://umc.minedu.gob.pe/wp-content/uploads/2017/04/ Libro_PISA.pdf. Accessed 22 Nov 2019.

Murillo, F. J., \& Román, M. (2011). School infrastructure and resources do matter: Analysis of the incidence of school resources on the performance of Latin American students. School Effectiveness and School Improvement, 22(1), 29-50. https://doi.org/10.1080/0924345 3.2010.543538.

Ñopo. (2017). https://twitter.com/hugonopo/status/892767867783041026

Organisation for Economic Co-operation and Development. (2017). PISA 2015 technical report. Available at: http://www.oecd.org/pisa. Accessed 26 Aug 2019.

Tapia, J., \& Cueto, S. (2017). El apoyo de FORGE al desarrollo del Currículo Nacional de la Educación Básica del Perú. Informe final. Lima: GRADE - Proyecto FORGE. http://repositorio.grade.org.pe/handle/GRADE/397. Accessed 22 Nov 2019.

The Economist, (2017). Latin America's battle over "gender ideology". https://www.economist.com/the-americas/2017/09/30/latin-americas-battle-over-gender-ideology. Accessed 26 Aug 2019.

Vargas, J.C. \& Cuenca, R. (2018). Perú: el estado de políticas públicas docentes. Instituto de Estudios Peruanos. http://repositorio.minedu.gob.pe/handle/MINEDU/5868. Accessed 22 Nov 2019.

Vílchez, K. M. R., \& Hurtado, N. S. (2018). El derecho a la educación intercultural bilingüe de la niñez indígena en el Perú: avances y desafíos. Persona y Familia, 1(7), 135-163. https://doi. org/10.33539/peryfa.2018.n7.1255.

What is the Diploma Programme. https://www.ibo.org/programmes/diploma-programme/what-isthe-dp/. Accessed 26 Aug 2019.

World Bank. (2017). World Development Report 2018. Learning to realize education's promise. The World Bank. https://openknowledge.worldbank.org/handle/10986/28340. Accessed 22 Nov 2019.

Yamada, G., Lavado, P., \& Oviedo, N. (2016). La evidencia de rendimientos de la educación superior a partir de "Ponte en Carrera" Documento de Discusión CIUP No. 16-08.

Open Access This chapter is licensed under the terms of the Creative Commons Attribution 4.0 International License (http://creativecommons.org/licenses/by/4.0/), which permits use, sharing, adaptation, distribution and reproduction in any medium or format, as long as you give appropriate credit to the original author(s) and the source, provide a link to the Creative Commons licence and indicate if changes were made.

The images or other third party material in this chapter are included in the chapter's Creative Commons licence, unless indicated otherwise in a credit line to the material. If material is not included in the chapter's Creative Commons licence and your intended use is not permitted by statutory regulation or exceeds the permitted use, you will need to obtain permission directly from the copyright holder.

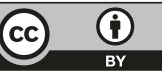

